\title{
Correlation between low-proficiency in English and negative perceptions of what it means to be an English speaker
}

\author{
Kavarljit Kaur Gill \\ 1Centre for Language Studies and Generic Development, Universiti Malaysia Kelantan, \\ Karung Berkunci 36, Pengkalan Chepa, 16100, Kota Bharu, Kelantan Darul Naim, Malaysia. \\ E-mail: kavarljitkaur@umk.edu.my \\ Andrew N Williams \\ 3Centre for Language Studies and Generic Development, Universiti Malaysia Kelantan, \\ Karung Berkunci 36, Pengkalan Chepa, 16100, Kota Bharu, Kelantan Darul Naim, Malaysia. \\ E-mail: andrew@umk.edu.my
}

Doi:10.7575/aiac.alls.v.4n.1p.109

URL: http://dx.doi.org/10.7575/aiac.alls.v.4n.1p.109
Received: $03 / 12 / 2012$

Accepted: 02/01/2013

\begin{abstract}
Learning another language is very much affected by positive or negative connotations attached to the new language by the language learner. Entering Malaysian public universities there are many students with a low proficiency in English, despite spending eleven years studying English in schools. Could it be that the lack of progress among these students could be attributed to a negative view of what it means to be a speaker of English? This study investigated the perceptions of students at a public university, to determine whether there is a correlation between low-proficiency and negative perceptions of what it means to be an English speaker. Analysis of the results showed that Malaysian students have a very positive perception of what it means to be an English speaker.
\end{abstract}

Keywords: Cultural perceptions; speaking English; Malaysian undergraduates; low proficiency.

\section{Introduction}

The history of English in Malaysia started during the colonial era and currently has spanned more than 200 years. During the colonial days, English was perceived as the language to improve socio-economic mobility as well as enhancing educational levels (Venugopal 2000). Being a multicultural country with fourteen states, English in Malaysia has been influenced by languages such as Malay, Chinese, Indian and other regional dialects. This has created a new variant of the language which is commonly known as Malaysian English (Ahmad Mahir, Silahudin Jarjis 2007:2).

In today's world, the role of English has increased tremendously. English has become the main international language as it plays a significant role in tertiary education, international socio-political correspondence, and as a medium for international interaction and knowledge exchange (Ahmad Mahir, Silahudin Jarjis 2007:2). It was shown by Pennycook (1994) that proficiency in an international language is required by countries that wish to acquire greater prestige and power.

As for education, studies such as Munawarah, Wan Nur Ayuni and Ikhwan Nisfu, (2006) have demonstrated that English is generally perceived as important by Malaysian students. Hj. Khamis, Nor Yazi (2007) however, have shown that there is no correlation between perception of the language and overall proficiency of students. This fact is echoed by the drop in English proficiency levels among Malaysian students in the past 30 years despite the language gaining more importance.

Looking at another perspective, Maros (1998) has demonstrated that language is closely related to culture. Culture and language are now believed to be more closely intertwined and studying one without the other has been demonstrated to be incomplete (Bada 2000:101). This could be illustrated by the scenario present in Malaysian schools where behaviours expected of students at schools differ from those expected at home, or when belief systems presented by teachers are inconsistent with those of childrens' parents. This has shown to cause children to be confused, unproductive and sometimes even angry or resistant (Hess, R. D., \& Holloway, S. D. 1984; Kumar, Gheen, \& Kaplan, 2002). Such culture shock would give a negative effect towards learning English as Second language.

Previous studies such as $\mathrm{Hj}$. Khamis, Nor Yazi (2007) have demonstrated no correlation between proficiency and perception of English Language. Such studies looked at the perception of students towards importance of English Language for employment and found a generally positive perception. It should be noted that although students might have positive perceptions towards English language, their perceptions towards their friends and people around them speaking in English might be very different. In fact, it is often commented that Malaysians (especially Kelantanese) are 
very negative towards other Malaysians around them using English. This might again be due to difference in set of beliefs and culture between the English speakers and the non-speaking students.

This study focuses on the perceptions of students towards people who speak English, a focus on the image of a Malaysian English speaker held by students. This might also include the set of belief, culture adopted by the Malaysian English speaker. In particular the study tested the following hypothesis:

1. Students with low proficiency of English (MUET Bands 1 and 2) have a negative perception of Malaysian English speakers.

2. Students of a Malay ethnicity have a more negative perception of English speakers than Malaysian students of other ethnicities.

3. Students from the states of Kelantan and Terengganu have a more negative perception of English speakers than Malaysian students of other ethnicities.

In addition this study also considered whether there was any difference in perception between male and female respondents.

The study was conducted in Universiti Malaysia Kelantan, a public university in the state of Kelantan.

\section{Materials and Methods}

\subsection{Experimental Design}

Data on the perceptions of university students was collected by the means of a questionnaire. The questionnaire consisted of eight statements; four representing positive statements about English speakers and four representing negative statements.

1. Malaysians who speak English are people who are proud.

2. Malaysians who speak English are people who do not value their own culture and traditions.

3. Malaysians who speak English are people who are influenced by negative Western values.

4. My friends don’t like to spend time with Malaysians who speak English.

5. Malaysians who speak English are people who are successful in their careers.

6. Malaysians who speak English are people who possess a gateway to

7. Malaysians who speak English are people who can relate well with all

8. Malaysians who speak English are people who I admire.

The respondents were asked to mark on a Liker scale their their degree of agreement, or disagreement with the statements. The Likert scale for the respondents' answers was as follows in Table 1:

Table 1. Likert scale for indicating agreement or disagreement

\begin{tabular}{|c|c|c|c|c|c|}
\hline $\begin{array}{l}\text { Strongly } \\
\text { Disagree }\end{array}$ & Disagree & $\begin{array}{l}\text { Somewhat } \\
\text { Disagree }\end{array}$ & Somewhat Agree & Agree & $\begin{array}{l}\text { Strongly } \\
\text { Agree }\end{array}$ \\
\hline 1 & 2 & 3 & 4 & 5 & 6 \\
\hline
\end{tabular}

The full questionnaire is included in Appendix A

\subsection{Respondents}

The respondents were chosen from intact, existing groups being taught English in their second year from two different faculties in a public university. 
Table 2. Descriptive Details of Respondents

Total number of respondents

113

\begin{tabular}{lll}
\hline Gender & & \\
\hline & Frequency & Percentage \\
Female & 77 & 68.1 \\
Male & 36 & 31.9 \\
\hline & & \\
\hline Ethnicity & & \\
\hline & Frequency & Percentage \\
Malay & 84 & 74.3 \\
Chinese & 17 & 15 \\
Indian & 8 & 7.1 \\
Sabah/Sarawak & 4 & 3.5 \\
Others & 0 & 0 \\
\hline
\end{tabular}

\begin{tabular}{lll}
\hline MUET Bands & & \\
\hline & Frequency & Percentage \\
1 & 36 & 31.9 \\
2 & 54 & 47.8 \\
3 & 22 & 19.5 \\
4 & 1 & 0.9 \\
5 & 0 & 0 \\
\hline
\end{tabular}

\begin{tabular}{lll}
\hline States & & \\
\hline & Frequency & Percentage \\
Johor & 11 & 9.7 \\
Kedah & 5 & 4.4 \\
Kelantan & 43 & 38.1 \\
Kuala Lumpur & 2 & 1.8 \\
Malacca & 1 & .9 \\
Melaka & 1 & .9 \\
Negeri Sembilan & 6 & 5.3 \\
Pahang & 3 & 2.7 \\
Penang & 4 & 3.5 \\
Perak & 6 & 5.3 \\
Sabah & 4 & 3.5 \\
Sarawak & 4 & 3.5 \\
Selangor & 9 & 8.0 \\
Terengganu & 14 & 12.4 \\
\hline
\end{tabular}

\subsection{Statistical Tests Used}

A Pearson Correlation test was used to examine correlation between the dependent variables (Likert scale responses indicating perceptions of English speakers) and independent variables (gender; ethnicity; home state and English ability given by MUET score). A "Positive Perception" index was created by taking the average score of responses for the positive perception statements $(5-8)$ and similarly a "Negative Perception" index was created by taking the average of the scores for responses to negative perception statements $(1-4)$. A Cronbach Alpha reliability test was carried out for these two indexes. These tests indicated that the Negative Perception Index was more reliable without statement 4, so this was removed from the analysis. The results are shown in Table 3. 
Table 3. Cronbach Alpha reliability test results

\begin{tabular}{ll}
\hline $\begin{array}{l}\text { Cronbach Alpha reliability test on Positive and Negative Perception } \\
\text { Indexes }\end{array}$ \\
\hline $\begin{array}{l}\text { Cronbach's } \\
\text { alpha }\end{array}$ \\
Positive Perception Index & 0.670 \\
(Statements 5 - 8) & \\
Negative Perception Index & 0.644 \\
(Statements 1 to 4) & \\
Negative Perception Index without Statement 4 & 0.653 \\
\hline
\end{tabular}

Since the Pearson Correlation test should be used with two interval or ratio variables, the variables Gender; State and Ethnicity were re-coded into dummy variables expressing "Maleness"; "East Coastness"; and "Malayness." Maleness was define as 1 for Male, 0 for Female; East Coastness was defined as 1 for Kelantan or Terengganu and 0 for all other states; Malayness was defined as 1 for Malay and 0 for all other ethnicities.

The Pearson Correlation test was carried out between these dummy variables and the Positive Perception Index and the Negative Perception Index without statement 4.

As a further investigation, a chi-squared test was carried out to determine any association between the independent variables (excluding MUET band) and responses to each of the eight satements. The Likert scale response was treated as a nominal variable for the purpose of this test.

\section{Results and Discussion}

This study examined whether university students with a low proficiency of English have a negative perception towards the idea of a Malaysian English speaker. In particular the following hypotheses were being tested:

1. Students with low proficiency of English (MUET Bands 1 and 2) have a negative perception of Malaysian English speakers.

2. Students of a Malay ethnicity have a more negative perception of English speakers than Malaysian students of other ethnicities.

3. Students from the states of Kelantan and Terengganu have a more negative perception of English speakers than Malaysian students of other ethnicities.

In addition this study also considered whether there was any difference in perception between male and female respondents.

The students who took part in this study gave answers that indicated very positive perceptions of Malaysian English speakers. These perceptions were assessed by a Likert scale questionnaire asking the degree to which the students agreed with positive and negative statements about Malaysian English speakers. The average of the responses to negative statements formed a Negative Perception Index and the average of the responses to the positive statements formed the Positive Perception Index. (For a clearer description of the range of responses possible please refer to Table 1 in the Methods section).

The following charts (Fig. 1 to 8 ) show the average index value for each of the factors under investigation in this study as possible factors influencing negative perceptions of English speakers.

\subsection{Negative Perceptions}

A lower score of 3 indicates some disagreement with a lower score a stronger disagreement with the negative statements about Malaysian English speakers, while a score of 4 indicates some agreement with a higher score indicating stronger agreement with the negative statements. 


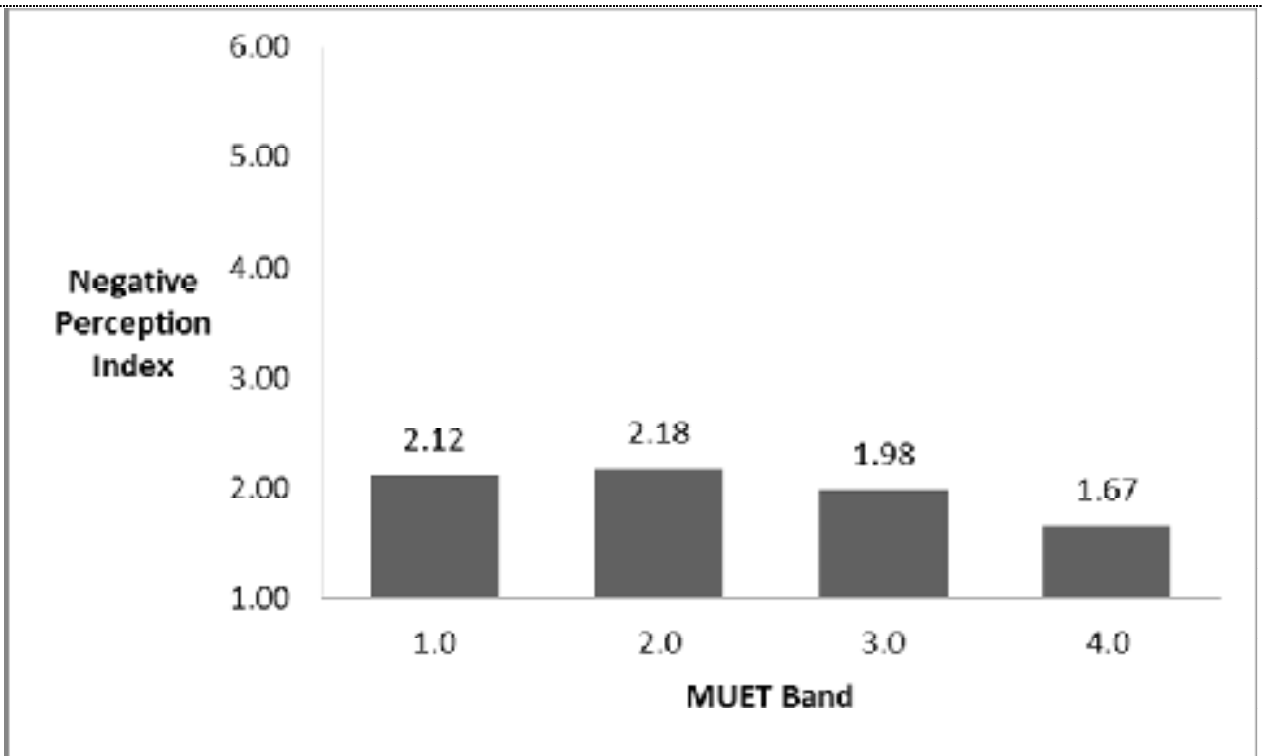

Fig.1: Relationship between Negative Perception Index and English ability represented by MUET score

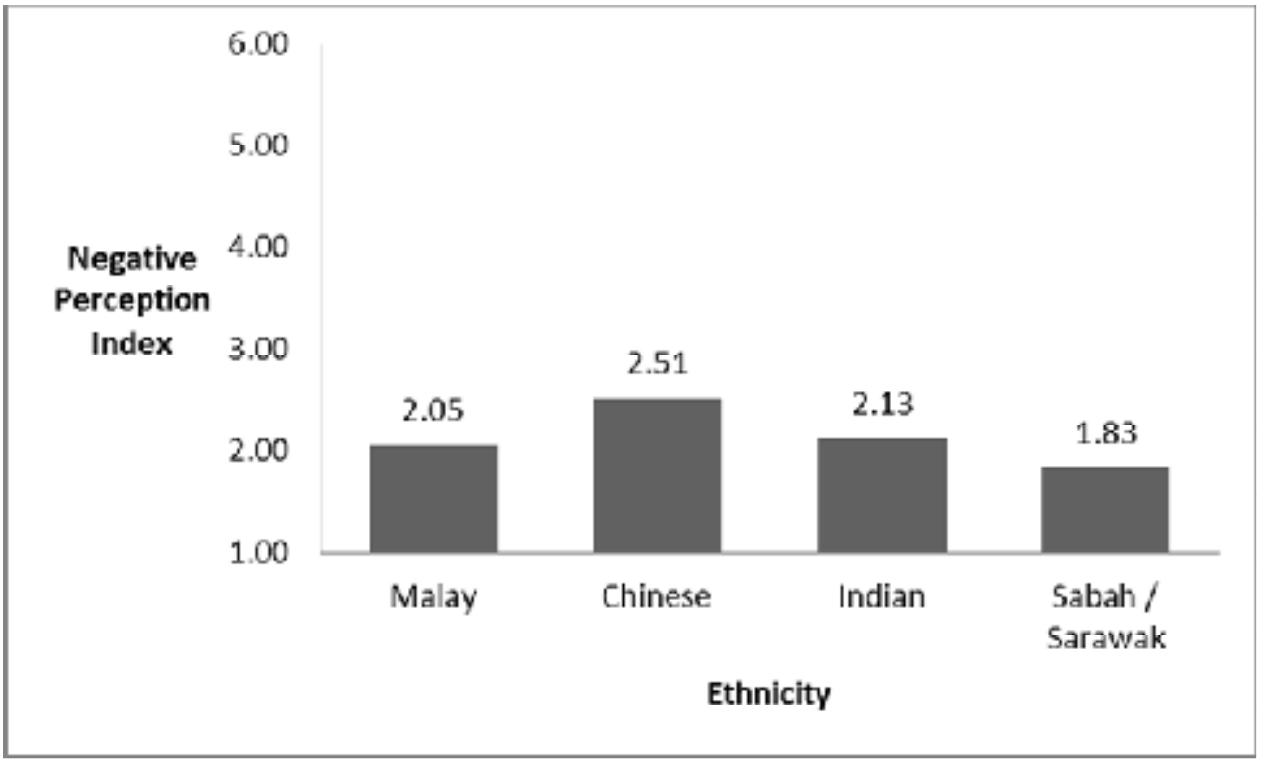

Fig. 2: Relationship between Negative Perception Index and Ethnicity

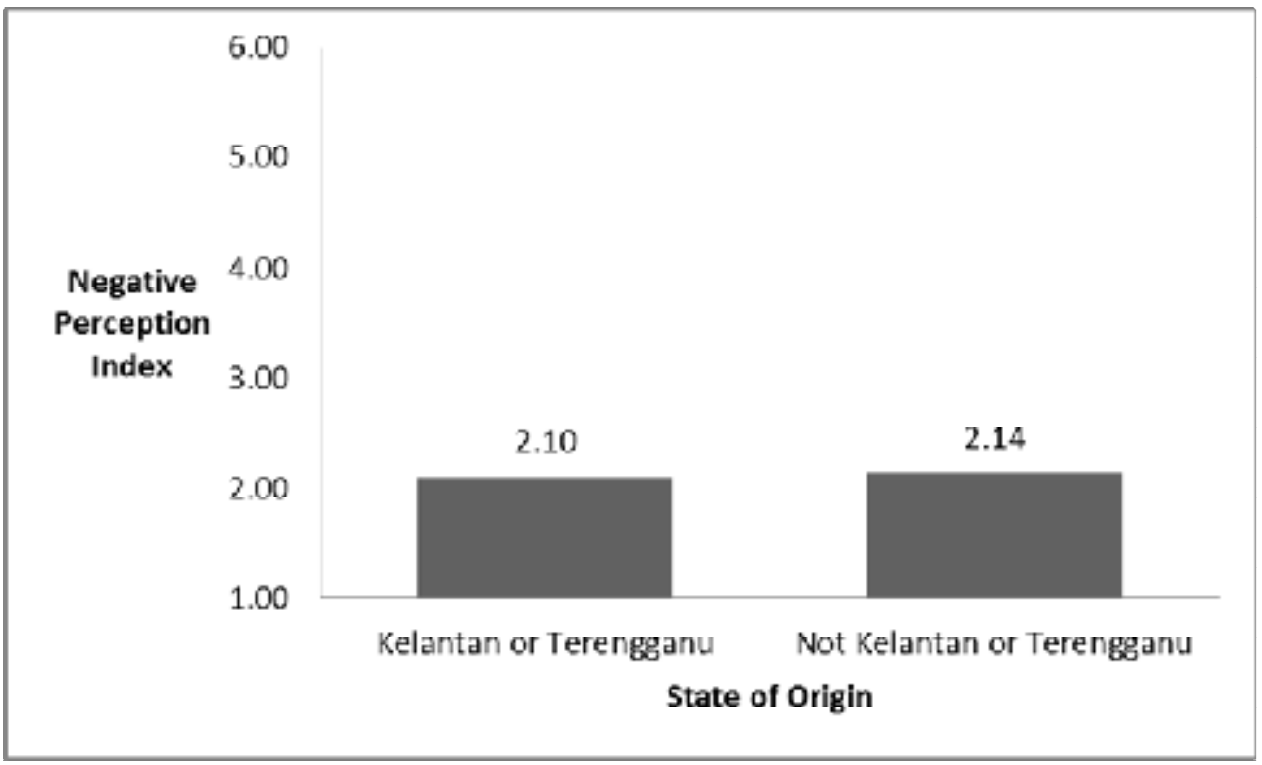

Fig. 3: Relationship between Negative Perception Index and State of Origin 


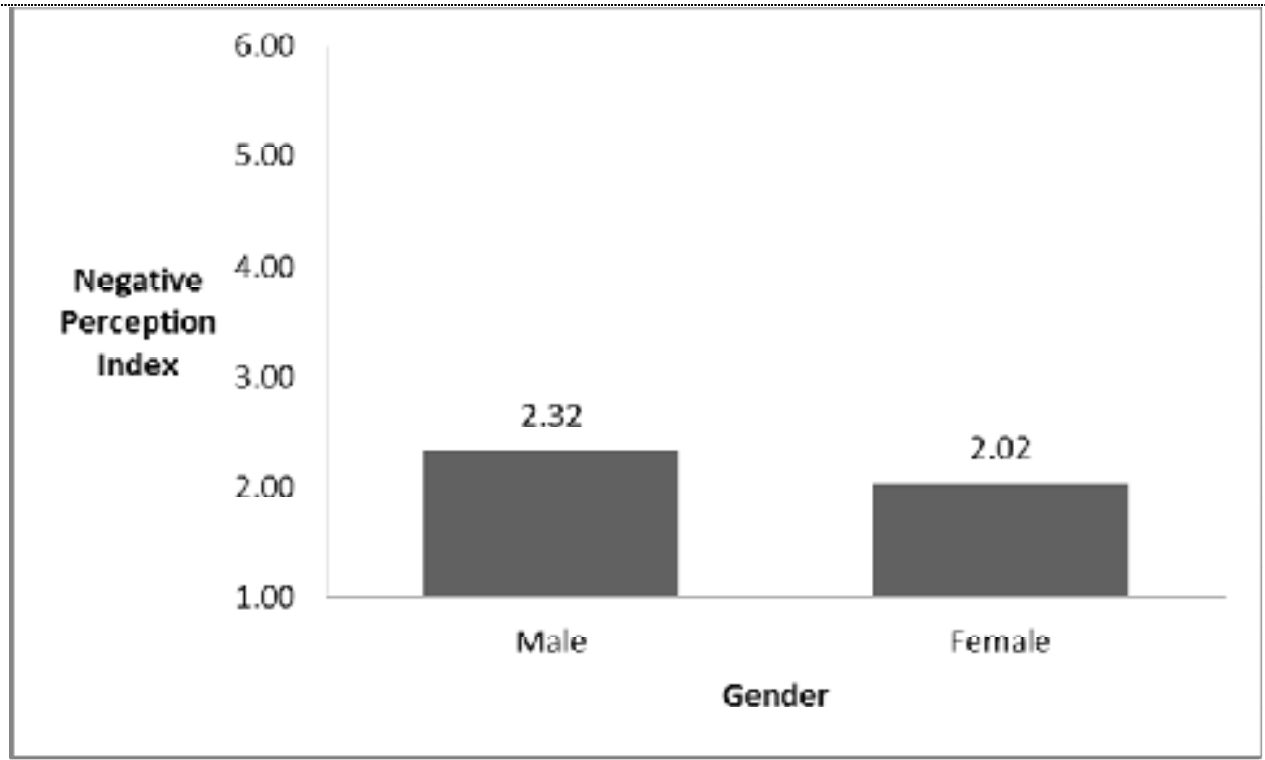

Fig. 4: Relationship between Negative Perception Index and Gender

\subsection{Positive Perceptions}

A lower score indicates stronger disagreement with the positive statements about Malaysian English speakers, while a higher score indicates stronger agreement with the positive statements.

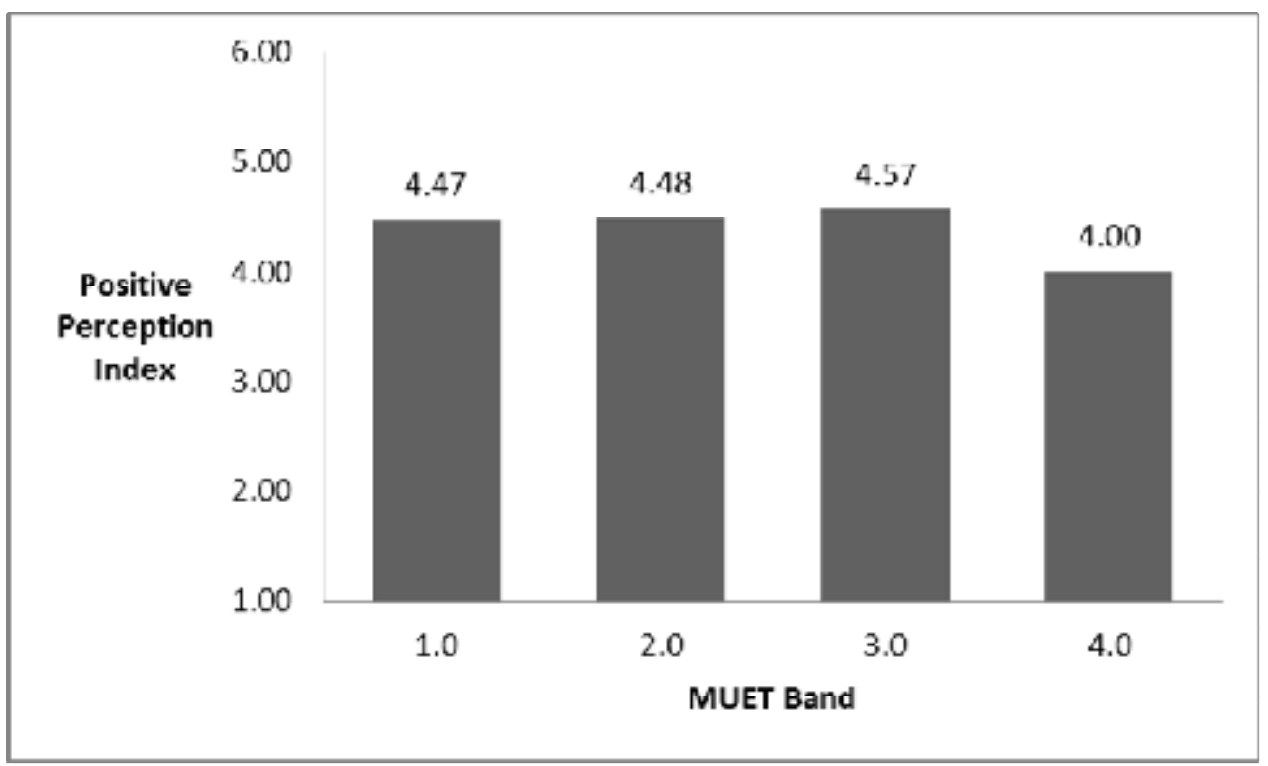

Fig. 5: Relationship between Positive Perception Index and English ability represented by MUET score.

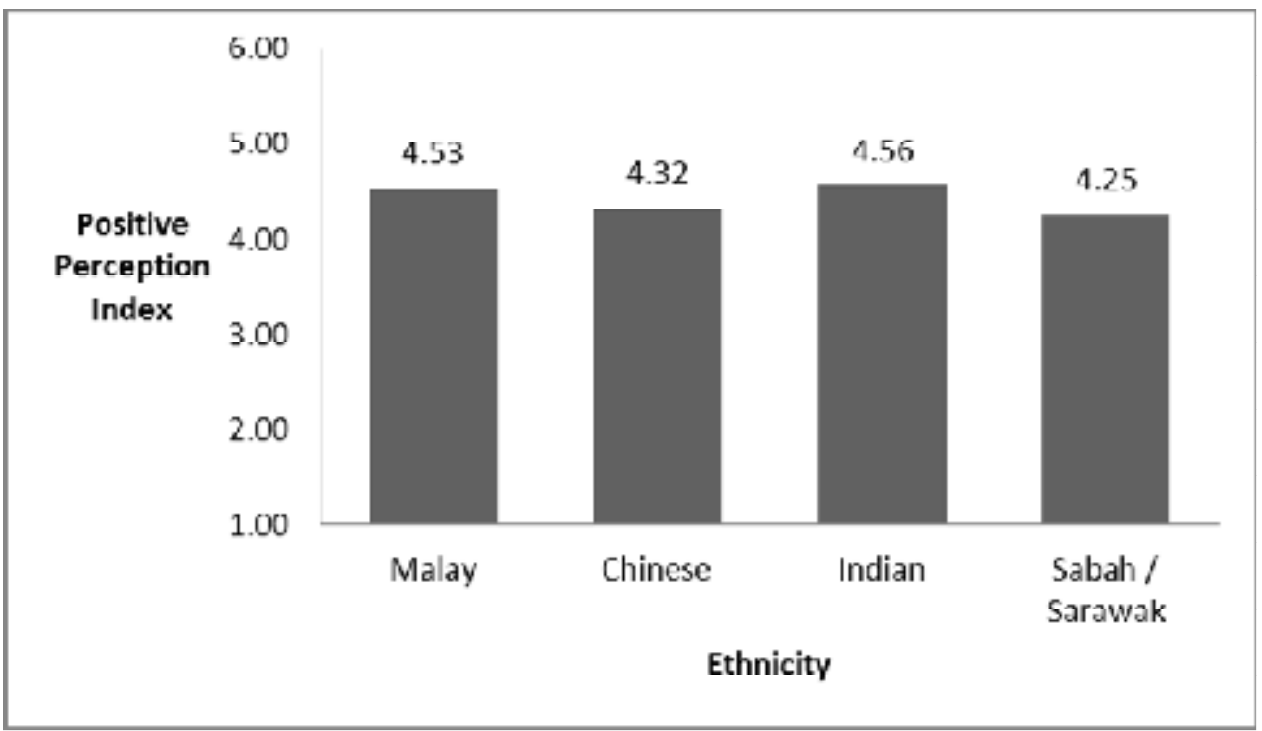

Fig. 6: Relationship between Positive Perception Index and Ethnicity 


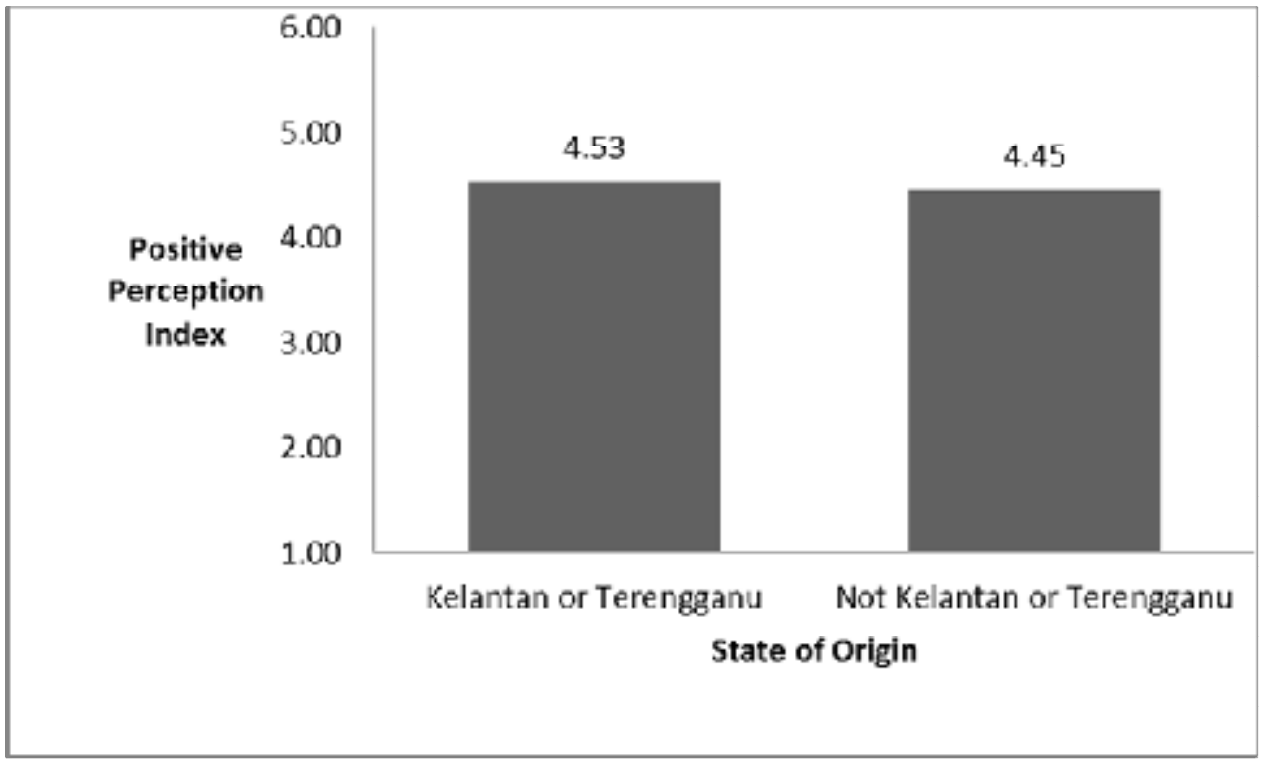

Fig. 7: Relationship between Positive Perception Index and State of Origin

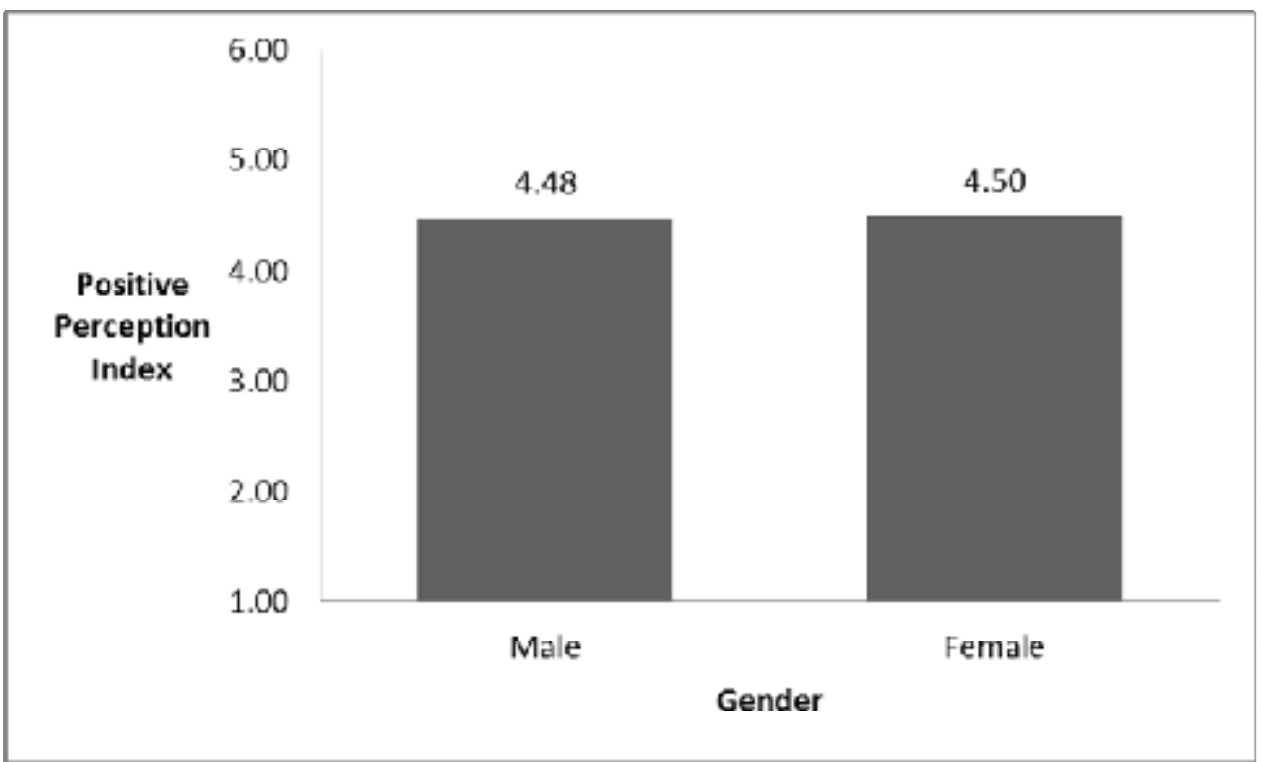

Fig. 8: Relationship between Positive Perception Index and Gender

What is immediately clear is the surprising result that perceptions towards Malaysian English speakers are very clearly positive. There was a conclusive agreement with positive perceptions and clear disagreement with negative perceptions. This study investigated whether level of English ability; ethnicity; state of origin; or gender has any relation to perceptions of English speakers. The results indicated in Fig. 1 to 8 clearly show that these factors have no affect on the perceptions of English speakers held by these respondents.

To further assess the results a Pearson Correlation test was carried out and the results are shown in Table 4

Table 4. Pearson Correlation of Factors affecting perceptions and perception indexes

\begin{tabular}{cccc}
\hline & & $\begin{array}{c}\text { Positive } \\
\text { Perception } \\
\text { Index }\end{array}$ & $\begin{array}{c}\text { Negative } \\
\text { Perception } \\
\text { Index }\end{array}$ \\
\hline MUET Band & & 0.023 & -0.061 \\
& Pearson Correlation & 0.812 & 0.518 \\
& Sig. (2-tailed) & 113 & 113 \\
\hline Male dummy variable & $\mathrm{N}$ & -0.011 & 0.183 \\
& Pearson Correlation & 0.908 & 0.052 \\
& Sig. (2-tailed) & 113 & 113 \\
\hline
\end{tabular}




\begin{tabular}{cccc}
\hline Malay dummy variable & Pearson Correlation & 0.088 & -0.147 \\
& Sig. (2-tailed) & 0.353 & 0.120 \\
& $\mathrm{~N}$ & 113 & 113 \\
\hline Kelantan and Terengganu dummy & Pearson Correlation & 0.054 & -0.024 \\
variable & Sig. (2-tailed) & 0.573 & 0.798 \\
& $\mathrm{~N}$ & 113 & 113
\end{tabular}

**. Correlation is significant at the 0.01 level (2-tailed).

*. Correlation is significant at the 0.05 level (2-tailed).

These results show no correlation between the factors between English ability; gender; ethnicity; and state of origin and the perceptions towards Malaysian English speakers. There is a slight correlation between gender and negative perceptions, but this is not significant. While the results for the overall positive and negative perception indexes are clear, there was also some analysis of the responses to each individual question. The percentage of respondents who agreed with each question is shown in Appendix B . To further examine these responses a Chi-squared test was done for association between the factors being examined and the responses given, the results are shown in table 5 .

Table 5. Chi-squared test of association between factors affecting perceptions and responses given by respondents

\begin{tabular}{|c|c|c|c|c|c|}
\hline & & MUET & Ethnicity & State & Gender \\
\hline & & Band & & & \\
\hline Proud & $\chi^{2}$ & 11.787 & 31.012 & 7.258 & 10.25 \\
\hline & $\mathrm{df}$ & 15 & 15 & 5 & 5 \\
\hline & $\mathrm{p}$ & 0.695 & $0.009 *$ & 0.202 & 0.068 \\
\hline Don't Value Culture & $\chi^{2}$ & 11.623 & 6.839 & 5.599 & 7.38 \\
\hline & $\mathrm{df}$ & 12 & 12 & 4 & 4 \\
\hline & $\mathrm{p}$ & 0.476 & 0.868 & 0.231 & 0.117 \\
\hline Influenced by Negative & $\chi^{2}$ & 11.396 & 13.85 & 7.178 & 2.844 \\
\hline Western Values & & & & & \\
\hline & $\mathrm{df}$ & 12 & 12 & 4 & 4 \\
\hline & $\mathrm{p}$ & 0.495 & 0.31 & 0.127 & 0.584 \\
\hline Friends don't like to spend & $\chi^{2}$ & 42.784 & 16.972 & 8.819 & 6.953 \\
\hline & $\mathrm{df}$ & 15 & 15 & 5 & 5 \\
\hline & $\mathrm{p}$ & $0^{*}$ & 0.321 & 0.117 & 0.224 \\
\hline Successful & $\chi^{2}$ & 5.978 & 15.236 & 1.586 & 2.023 \\
\hline & $\mathrm{df}$ & 15 & 15 & 5 & 5 \\
\hline & $\mathrm{p}$ & 0.98 & 0.432 & 0.903 & 0.846 \\
\hline Possess a Gateway to & $\chi^{2}$ & 6.958 & 14.863 & 2.578 & 6.738 \\
\hline Knowledge & & & & & \\
\hline & df & 12 & 12 & 4 & 4 \\
\hline & $\mathrm{p}$ & 0.86 & 0.249 & 0.631 & 0.15 \\
\hline Relate well with others & $\chi^{2}$ & 16.364 & 11.579 & 1.825 & 5.4 \\
\hline & $\mathrm{df}$ & 12 & 12 & 4 & 4 \\
\hline & $\mathrm{p}$ & 0.175 & 0.48 & 0.768 & 0.249 \\
\hline Admired & $\chi^{2}$ & 9.568 & 22.317 & 4.056 & 9.869 \\
\hline & $\mathrm{df}$ & 15 & 15 & 5 & 5 \\
\hline & $\mathrm{p}$ & 0.846 & 0.1 & 0.541 & 0.079 \\
\hline
\end{tabular}


These results seem to show some association between ethnicity and the agreement or disagreement with the statement that Malaysians who speak English are proud. Table 6 shows the figures in more detail

Table 6. Percentages of ethnic groups that agreed with the statement that English speakers are proud

\begin{tabular}{lllll}
\hline & Malay & Chinese & Indian & Sabah / Sarawak \\
Disagree & $89.3 \%$ & $52.9 \%$ & $75.0 \%$ & $100 \%$ \\
Agree & $10.7 \%$ & $47.1 \%$ & $25.0 \%$ & $0 \%$ \\
\hline
\end{tabular}

There are two possible factors that may have adversely affected these results. Firstly, the number of respondents from each non-Malay ethnic group was very small in comparison with the number from the Malay ethnic group. This may have skewed the results. Secondly, the use of the word "proud" may have had opposite meanings for different ethnic groups. Even though this word was translated into Malay it is possible that some of the Chinese ethnic group and Indian ethnic group may have considered that being proud is a positive characteristic while it was actually intended to communicate a negative characteristic.

The Chi-squared table also appears to show an association between English ability (given by MUET band) and agreement with the perception that the respondent's friends don't like to spend time with English speakers. However, closer inspection of the results showed that there was only one respondent with MUET band 4 and the response of this person skewed the results.

Thus, while there is a possibility of some association between ethnicity and perceptions that Malaysians who speak English are proud, Malays clearly do not agree with this perception. The remaining factors do not appear to have any association with the perceptions held by the respondents.

Khamis (2007) investigated Malaysian student perceptions towards the importance of English for the workplace. While this was focused on a different area her results showed that female students were more positive than male students and students from the West Coast more positive than those from the East Coast. In the current study these factors of gender and state of origin had no effect upon the perceptions of the students.

In summary, all the hypothesis under investigation have to be rejected: Malaysian university students in this study appear to have strongly positive perceptions of Malaysian English speakers and English ability, ethnicity, state of origin and gender have no effect upon the perceptions held by these students.

Of particular interest is the results for the statement "My friends don't like to spend time with Malaysians who speak English"; the students in this study clearly did not agree with this statement. However, annectodotal evidence would suggest that students often make fun of other students who speak English. This would suggest a negative perception but maybe the way the question was phrased caused this negative perception not to be present in the responses of the students. It is also possible that the sentiments that cause students to make fun of English speakers are not related to perceptions of culture.

\section{Conclusion}

The results show that students have positive perceptions towards English speakers, rejecting statements that express negative perceptions and agreeing with statements that express positive perceptions.

However, the question which remains in the mind is: what causes students to react negatively to their friends speaking English? It is possible that this could be caused by a negative perception towards English speakers that was not identified through the questionnaire that was used. Another possibility is that this reaction is not caused by negative perception towards English speakers, but rather by some other factors such as sociological factors.

This study has shown surprising results that Malaysians are generally positive towards other Malaysians speaking English, but it leaves some unanswered questions about Malaysian students making fun of their friends when they speak English.

\section{References}

Ahmad Mahir, Silahudin Jarjis (2007). The Use of Malay Malaysian English in Malaysian English: Key Considerations In: The Second Biennial International Conference On Teaching and Learning English in Asia: Exploring New Frontiers (TELiA2), 14-16 June 2007 Holiday Villa Beach \& Spa Resort, Langkawi, Faculty of Communication and Modern Languages, Universiti Utara Malaysia, Sintok, pp 1-9.

Bada, E. (2000). Culture in ELT. Cukurova University Journal of Social Sciences (6), 100-110.

Hess, R. D., \& Holloway, S. D. (1984). Family and school as educational institutions. In |R. Parke (Ed.), Review of child development research. Vol. 7. (pp. 179-222). Chicago: University of Chicago Press.

Kumar, R Gheen, MH, \& Kaplan, A. (2002) Goal Structures in The Learning Environment and students' disaffection from Learning and schooling. In C. Midgley (Ed.), Goals, Goals structures and patterns of adaptive learning (pp. 
Venugopal, S. Nair. (2000). Language Choice and Communication in Malaysian Business. Bangi: Penerbit Universiti Kebangsaan Malaysia.

Munawarah, Wan Nur Ayuni and Ikhwan Nisfu (2006). The usage and perception of the English Language among $B$. Ed (TESL) Foundation Cohort 3 IPBA students. Educational Research Seminar for Students

IPBA. Retrieved November 10, 2013, from http://apps.emoe.gov.my/ipba/ResearchPaper/stdntseminar/pg49to58.pdf

Marlyna Maros. (1998). A Sociolinguistics Window to Cultural Change. Fakulti Pengajian Bahasa, Universiti Kebangsaan Malaysia

Pennycook, A. (1994). The cultural politics of English as an international language. London: Longman

\section{APPENDIX A}

Questionnaire used to collect respondents' perceptions

Questionnaire on Perceptions of English Speakers Soal Selidik mengenai Persepsi Penutur Bahasa Inggeris

\begin{tabular}{|c|c|c|c|}
\hline $\begin{array}{l}\text { Matric No.: } \\
\text { No. Matrik }\end{array}$ & $\begin{array}{l}\text { Gender: } \\
\text { Jantina }\end{array}$ & $\begin{array}{l}\text { Male / } \\
\text { Female }\end{array}$ & $\begin{array}{r}\text { Ethnicity: } \\
\text { Etnik }\end{array}$ \\
\hline $\begin{array}{l}\text { Faculty: } \\
\text { Fakulti }\end{array}$ & Year of Study: & & $\begin{array}{l}\text { MUET Band: } \\
\text { Band MUET: }\end{array}$ \\
\hline $\begin{array}{r}\text { State: } \\
\text { Negeri: }\end{array}$ & $\begin{array}{r}\text { Number of } \\
\text { siblings: } \\
\text { Bilangan adik- } \\
\text { beradik: }\end{array}$ & & $\begin{array}{r}\text { States of siblings: } \\
\text { Status Kenegerian } \\
\text { adik-beradik: }\end{array}$ \\
\hline
\end{tabular}

This questionnaire is about what you think of Malaysians who speak English. There are no 'right' or 'wrong' answers; we need to know how you feel. For each of the questions place circle the number in the scale below that best describes to what extent you agree with the statements.

Soal selidik ini adalah untuk mendapatkan pandangan Rakyat Malaysia terhadap mereka yang menggunakan Bahasa Inggeris. Tidak ada jawapan 'betul' atau 'salah' bagi soalan yang diberi. Kami cuma ingin mengetahui persepsi anda berhubung dengan perkara ini. Untuk setiap soalan, sila bulatkan nombor di skala dibawah yang memberikan gambaran yang tepat mengenai kenyataan yang paling hampir dengan persepsi anda.

Scale/ Skala

\begin{tabular}{|l|l|l|c|l|l|}
\hline $\begin{array}{l}\text { Strongly } \\
\text { Disagree } \\
\text { Sangat Tidak } \\
\text { Setuju }\end{array}$ & $\begin{array}{l}\text { Disagree } \\
\text { Tidak Setuju }\end{array}$ & $\begin{array}{l}\text { Somewhat } \\
\text { Disagree } \\
\text { Agak tidak } \\
\text { Bersetuju }\end{array}$ & $\begin{array}{l}\text { Somewhat Agree } \\
\text { Agak Bersetuju }\end{array}$ & $\begin{array}{l}\text { Agree } \\
\text { Setuju }\end{array}$ & $\begin{array}{l}\text { Strongly } \\
\text { Agree } \\
\text { Sangat Setuju }\end{array}$ \\
\hline 1 & 2 & 3 & 4 & 5 & 6 \\
\hline
\end{tabular}

1. Malaysians who speak English are people who are proud.

Rakyat Malaysia yang berbahasa Inggeris adalah mereka yang suka 'bangga diri'.

\begin{tabular}{|l|l|l|l|l|l|}
\hline 1 & 2 & 3 & 4 & 5 & 6 \\
\hline
\end{tabular}

2. Malaysians who speak English are people who do not value their own culture and traditions.

Rakyat Malaysia yang berbahasa Inggeris adalah mereka yang tidak menghargai kebudayaan dan adat resam mereka.

\begin{tabular}{|l|l|l|l|l|l|}
\hline 1 & 2 & 3 & 4 & 5 & 6 \\
\hline
\end{tabular}

3. Malaysians who speak English are people who are influenced by negative Western values.

Rakyat Malaysia yang boleh berbahasa Inggeris adalah mereka yang terpengaruh dengan pelbagai anasir budaya Barat yang negetif.

\begin{tabular}{|l|l|l|l|l|l|}
\hline 1 & 2 & 3 & 4 & 5 & 6 \\
\hline
\end{tabular}

4. My friends don't like to spend time with Malaysians who speak English.

Rakan-rakan saya tidak suka menghabiskan masa dengan orang Malaysia yang berbahasa Inggeris.

\begin{tabular}{|l|l|l|l|l|l|}
\hline 1 & 2 & 3 & 4 & 5 & 6 \\
\hline
\end{tabular}


5. Malaysians who speak English are people who are successful in their careers.

Rakyat Malaysia yang boleh berbahasa Inggeris adalah terdiri daripada mereka yang sudah berjaya dalam kerjaya mereka.

\begin{tabular}{|l|l|l|l|l|l|}
\hline 1 & 2 & 3 & 4 & 5 & 6 \\
\hline
\end{tabular}

6. Malaysians who speak English are people who possess a gateway to knowledge through their ability to communicate in English.

Rakyat Malaysia yang boleh berbahasa Inggeris adalah mereka yang mempunyai peluang yang cerah untuk menimba pengetahuan melalui kepakaran bahasa mereka.

\begin{tabular}{|l|l|l|l|l|l|}
\hline 1 & 2 & 3 & 4 & 5 & 6 \\
\hline
\end{tabular}

7. Malaysians who speak English are people who can relate well with all the different race and ethnic groups in Malaysia.

Rakyat Malaysia yang boleh berbahasa Inggeris adalah mereka yang boleh berhubungan secara baik dengan pelbagai bangsa dan kaum di Negara ini.

\begin{tabular}{|l|l|l|l|l|l|}
\hline 1 & 2 & 3 & 4 & 5 & 6 \\
\hline
\end{tabular}

8. Malaysians who speak English are people who I admire.

Saya mengagumi Rakyat Malaysia yang boleh berbahasa Inggeris.

\begin{tabular}{|l|l|l|l|l|l|}
\hline 1 & 2 & 3 & 4 & 5 & 6 \\
\hline
\end{tabular}

End of Survey

Soal Selidik Tamat

\section{APPENDIX B}

Percentages of participants in each category who agreed with the statements (chose a Likert scale answer of 4, 5, or 6)

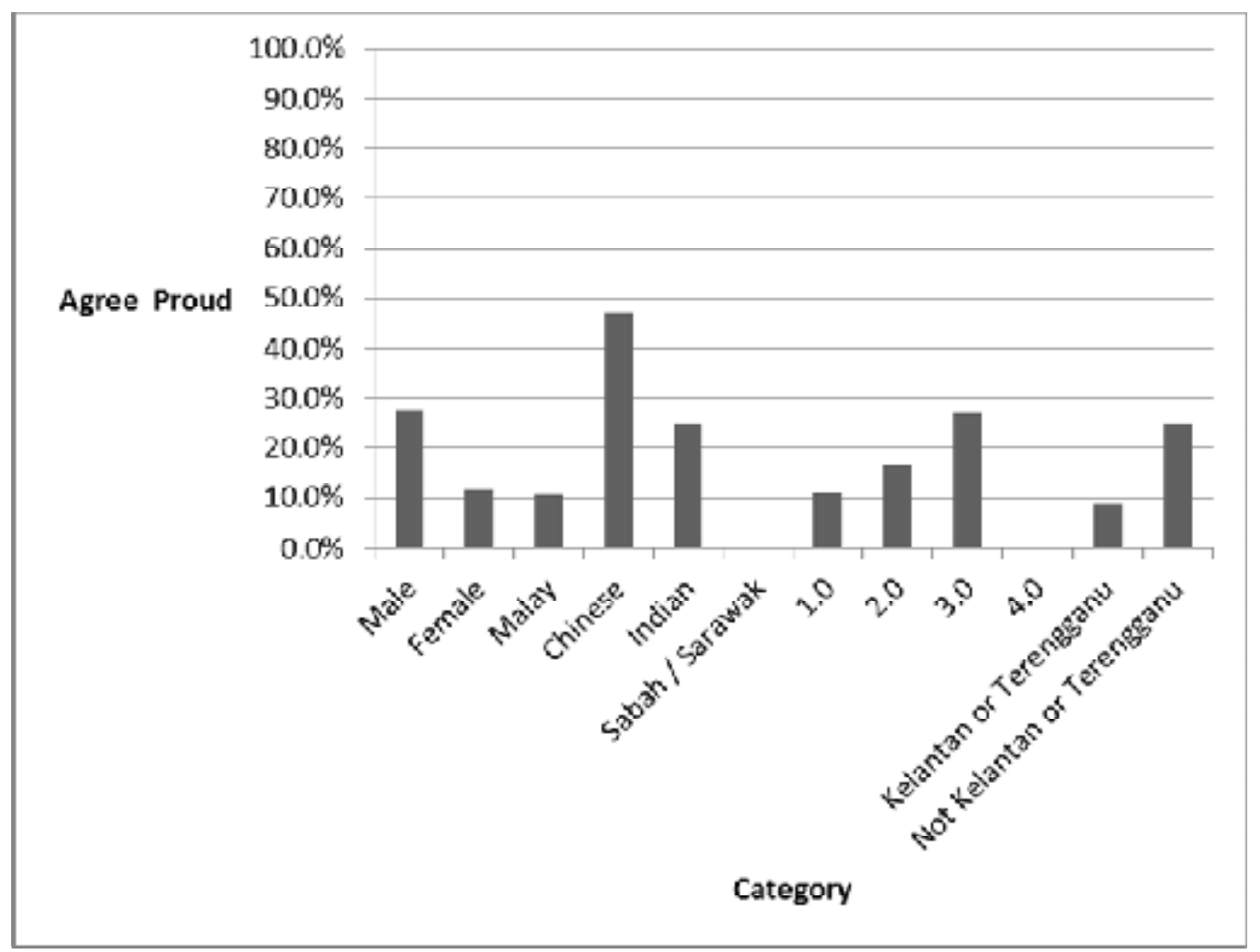



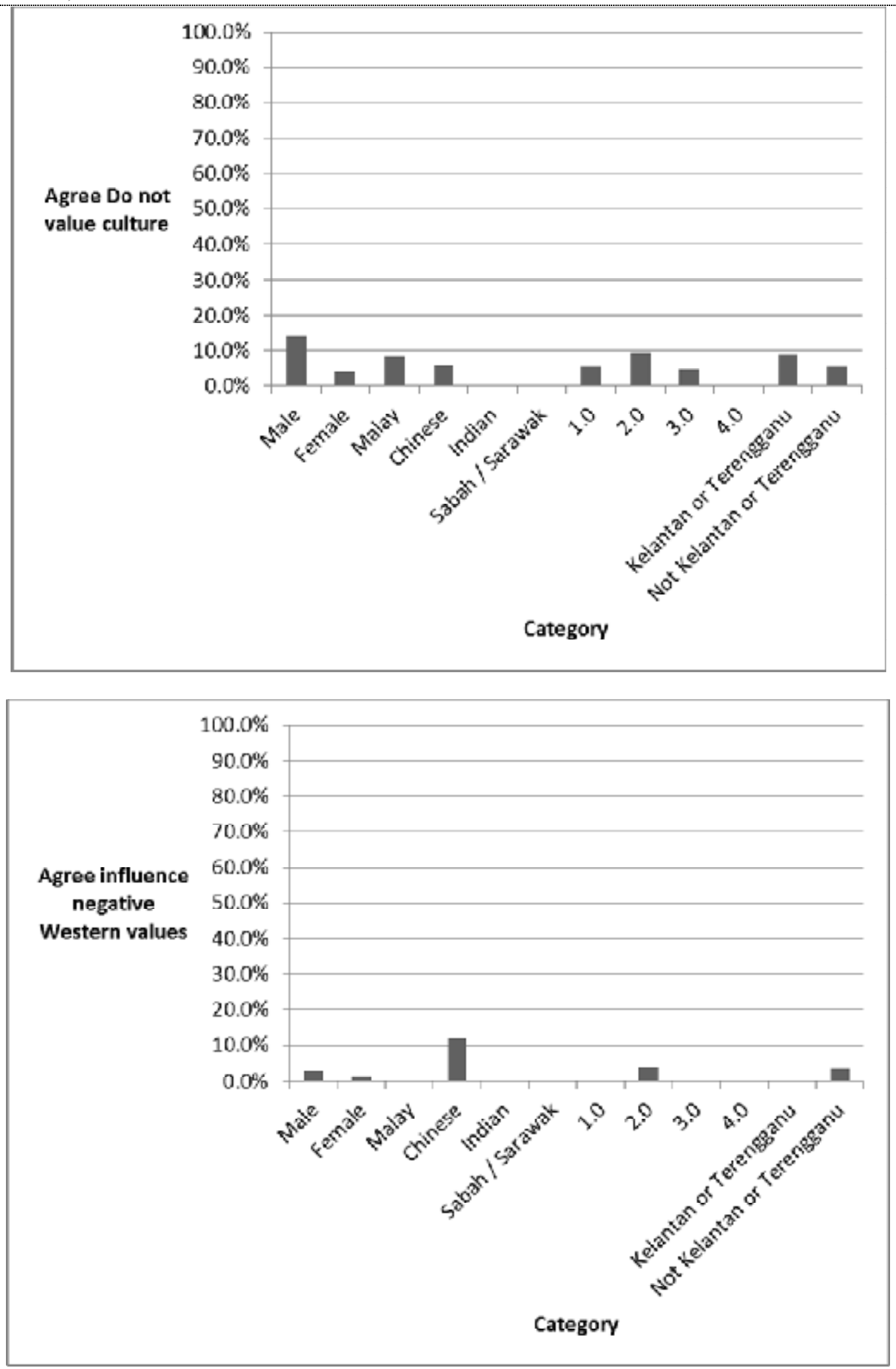

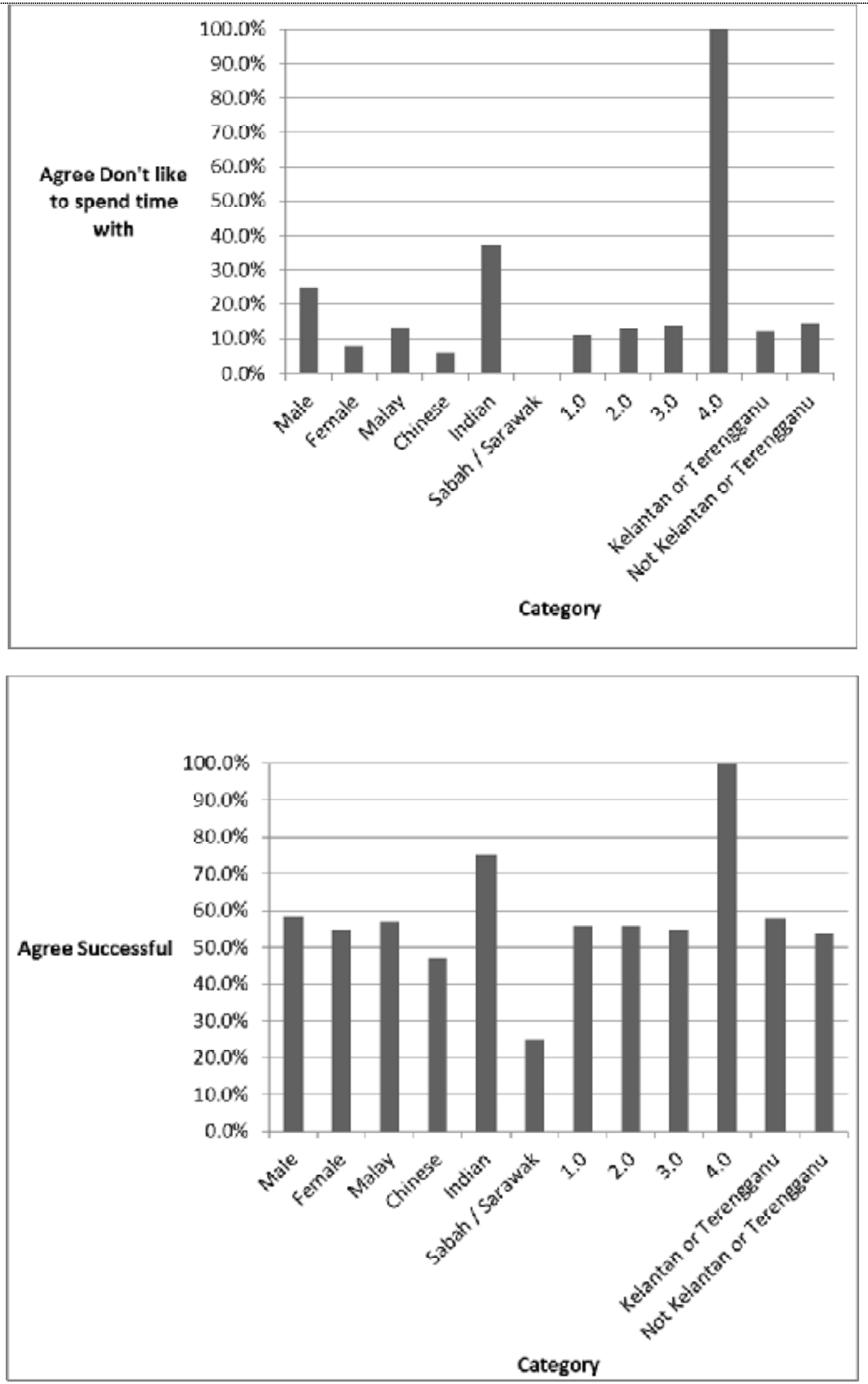

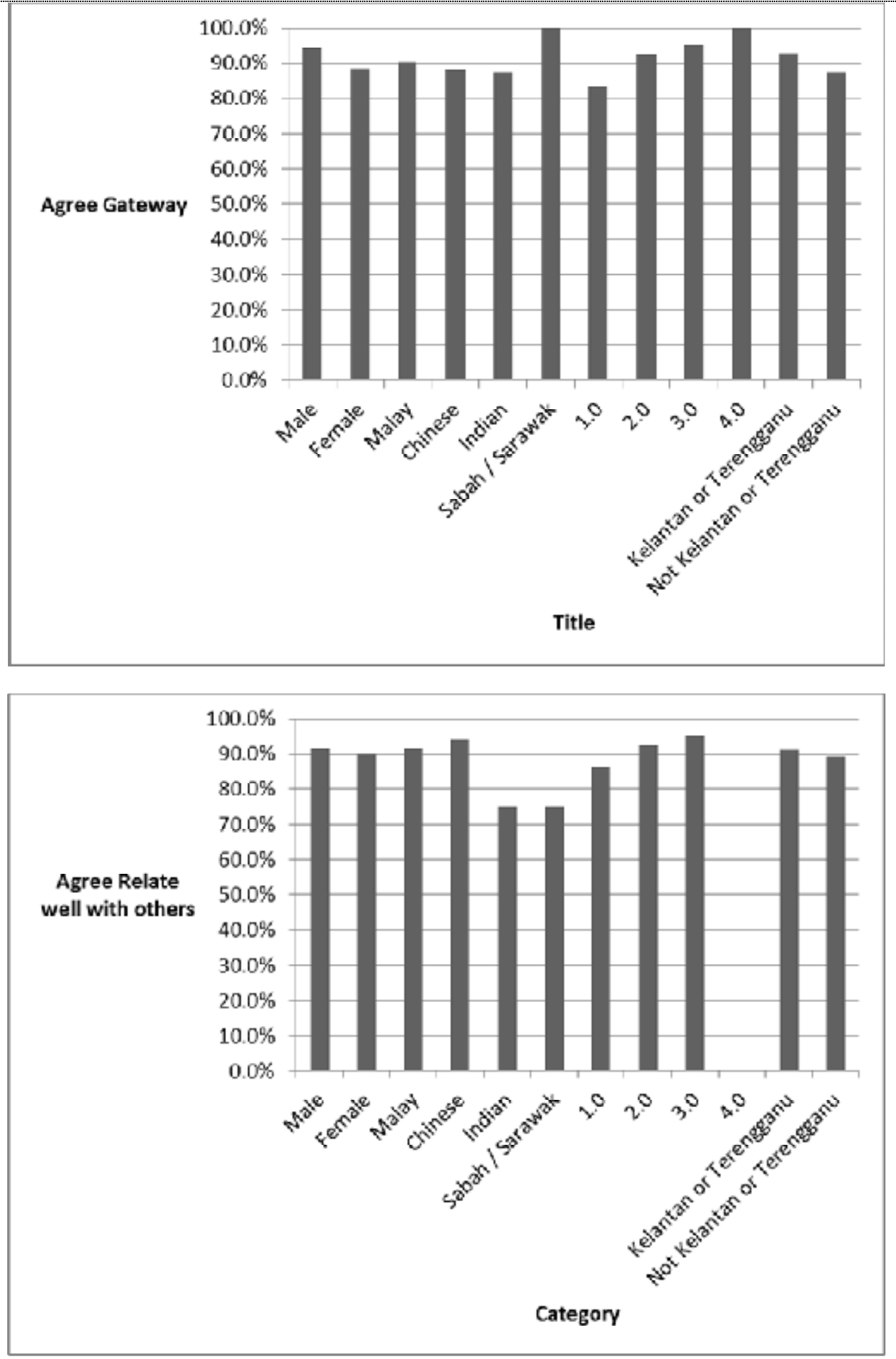


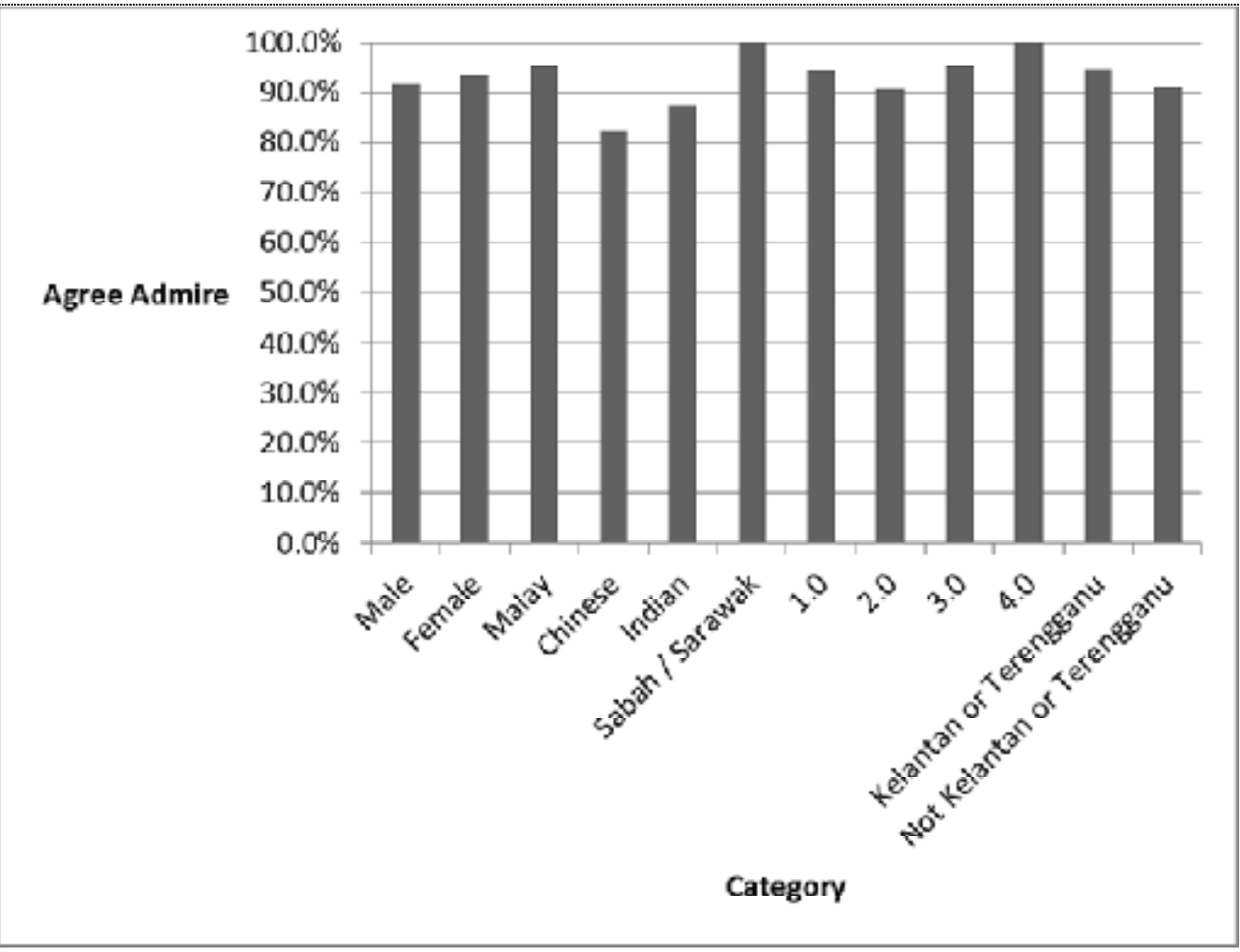

